\title{
Low dose mifepristone in the treatment of uterine leiomyoma
}

\author{
U. S. Hangarga ${ }^{1}$, Rita $D^{2}$
}

\begin{abstract}
${ }^{1}$ Department of Obstetrics and Gynaecology, Navodaya Medical College, Raichur, Karnataka, India
${ }^{2}$ Department of Obstetrics and Gynaecology, S. D. M. Medical College, Dharwad, Karnataka, India
\end{abstract}

Received: 30 November 2016

Revised: 05 December 2016

Accepted: 06 December 2016

\section{*Correspondence:}

Dr. U. S. Hangarga,

E-mail: drushangarga@gmail.com

Copyright: ( $\odot$ the author(s), publisher and licensee Medip Academy. This is an open-access article distributed under the terms of the Creative Commons Attribution Non-Commercial License, which permits unrestricted non-commercial use, distribution, and reproduction in any medium, provided the original work is properly cited.

\begin{abstract}
Background: To determine and evaluate the effectiveness of low dose of mifepristone in the management of symptomatic leiomyoma.

Methods: It is a randomized prospective observational before after treatment study of 50mg mifepristone once weekly for 24 weeks (6 Months). The study was conducted at Navodaya Medical College Hospital and Research Centre, Raichur. The study period was Jan-June 2016; the total of 30 patients was enrolled in the study. Sample size was calculated to study changes in various parameters after 6 months of treatment with mifepristone $50 \mathrm{mg}$ weekly. Basic investigations were performed, which includes $\mathrm{Hb} \%$, LFT, RFT, Complete Hemogram, USG examinations including Doppler study and menstrual blood loss was calculated through pictoral blood assessment chart.

Improvement of the patient was assessed at 1,3 and 6 months.

Results: The majority of our study group patients belong to between $40-45$ years and $66 \%$ of patients were para- 2 . The most important dominant symptom was menorrhagia, out of 30 patients, 27 had excessive blood loss during periods (90\%). All 30 cases were subjected to endometrial biopsy before starting of treatment; there was a change in the endometrial pattern after treatment. The marked changes in the endometrium were simple endometrial hyperplasia and decrease in the normal endometrial pattern after treatment. In the present study after starting the treatment there was reduction in menstrual blood loss observed in $90 \%$ of patients and $75 \%$ of patients' attained amenorrhea at the end of treatment, improvement in haemoglobin parameter in the study group. The size of fibroids was also decreased. Conclusions: Low dose mifepristone treatment for leiomyoma is more efficacious and useful to the patient. Drug helped in reliving the symptoms of the patient to a greater extent.
\end{abstract}

Keywords: Amenorrhea, Fibroid- Leiomyoma, Mifepristone, Medical management, Uterine volume

\section{INTRODUCTION}

The Uterine myoma is the common benign pelvic tumors, many a times it incapacitate women due to menorrhagia, dysmenorrhea, pelvic pain and other symptoms. The incidence cited as about $22-25 \%$ and majority of fibroid remains asymptomatic, when symptoms are present most important is menstrual disturbances, abdominal lump, pelvic pain, infertility and other pressure effects. Mifepristone is a selective progesterone receptor binding modulator with primary antagonist properties.
It binds to endometrial progesterone receptors minimally estrogen receptors and up regulates androgen receptors. In many of placebo control trials of Mifepristone has been shown to decrease myoma size and as well symptoms. ${ }^{1-4}$ Reduction in the fibroid size with Mifepristone might be due to direct effect on in reducing the number of progesterone receptors. Increase in androgen receptors also contributes to the antiprogesteronic effect. Mifepristone also delays or inhibits ovulation which may produce amenorrhea. Direct suppressive effect on endometrial vasculature as well as on reducing stromal vascular endothelial growth factor has also been suggested for reducing menstrual blood loss. Therefore this study designed to evaluate efficacy 
and safety of mifepristone in medical management of uterine fibroid or leiomyoma.

The non-surgical treatment options for myoma are limited. Danazol reduces the volume of uterine fibroid but associated with marked androgenic side effects.

Gonadotrophic releasing hormones agonist reduces the size of myoma up to $50 \%$ but it is more expensive.

Uterine artery embolisation has been shown to decreases myoma by $35-60 \%$, improves menorrhagia reduces the pelvic pain but there are potential risk of premature ovarian failure and uterine synaechi.

\section{METHODS}

The randomized observational prospective before-after study was conducted on 30 patients having symptomatic leiomyoma. The study was undertaken at NMCH which is a tertiary care teaching hospital, Raichur.

This study was conducted between Jan 2016 to June 2016. Total 30 symptomatic patients were recruited for the study and written consent of patients was taken. A complete general; Gynaecological examination was done. Blood testing was done for hemoglobin, LFT, RFT were done. Ultrasound was done to confirm diagnosis and ascertain number site volume and measurement of endometrial thickness.

Fibroid volume was calculated by ellipsoid method and formula $\mathrm{V}=0.5233$ (D1, D2, D3) used. When D1, D2 and D3 are longitudinal, transverse and cross sectional diameters of the fibroid respectively. In multiple leiomyomas all volumes are added. Doppler ultrasound was done, the uterine artery resistive index (RI) and pulsatility index (PI) was noted. Endometrial aspiration was done before starting the treatment to know endometrial pattern. The clinical profile including menstrual cycle, symptoms and severity was noted.

The assessment of menstrual blood loss was done by pictorial blood loss assessment chart. It is a semi quantitative that takes into account of number of pads soaked, passage of clots. PBAC score more than 100 suggest more amount of bleeding that is menorrhagia. The tablets of mifepristone are available in the market in the strength of $200 \mathrm{mgs}$. Tablets are made into 4 portions and asked the patient to take $1 / 4^{\text {th }}$ every week. Patients are regularly followed at 1 month, 3 month and 6 month intervals, on every visit; clinical symptoms amount of bleeding and amenorrhea. Ultrasound was done to note down the number, size of fibroids and endometrial thickness.

\section{RESULTS}

The most important dominant symptom was menorrhagia, out of 30 patients, 27 had excessive blood loss during periods $(90 \%)$.

Table 1: Age wise distribution.

\begin{tabular}{|lll|}
\hline Age (Yrs) & No. of cases & Percentages \\
\hline $30-34$ & 5 & 17 \\
\hline $35-39$ & 10 & 33 \\
\hline$>=40$ & 15 & 50 \\
\hline Total & 30 & 100 \\
\hline
\end{tabular}

Table 2: Parity distribution.

\begin{tabular}{|lll|}
\hline Parity & No. of cases & Percentages \\
\hline Nulliparous & 2 & 6.67 \\
\hline Primiparous & 8 & 26.67 \\
\hline Multiparous & 20 & 66.67 \\
\hline Total & 30 & 100.00 \\
\hline
\end{tabular}

Table 3: Symptom wise distribution of cases and improvement.

\begin{tabular}{|llll|}
\hline Symptoms & $\begin{array}{l}\text { Before } \\
\text { treatment } \\
\text { total cases }\end{array}$ & $\begin{array}{l}\text { Reduction in } \\
\text { symptom after } \\
\text { treatment }\end{array}$ \\
\hline No. of cases & No. of cases & $\%$ \\
\hline Menorrhagia & 30 & 27 & 90 \\
\hline Dysmenorrhoea & 30 & 25 & 83 \\
\hline Pelvic pain & 30 & 20 & 67 \\
\hline Urinary complaints & 8 & 6 & 75 \\
\hline Dyspareunia & 10 & 5 & 50 \\
\hline
\end{tabular}

Table 4: Endometrial changes before-after treatment.

\begin{tabular}{|lll|}
\hline Endometrium & $\begin{array}{l}\text { Before } \\
\text { treatment }\end{array}$ & $\begin{array}{l}\text { After } \\
\text { treatment }\end{array}$ \\
\hline Normal proliferation & 18 & 12 \\
\hline $\begin{array}{l}\text { Atrophic endometrium } \\
\text { disordered }\end{array}$ & 0 & 0 \\
\hline $\begin{array}{l}\text { Endometrium secretory } \\
\text { hyperplasia }\end{array}$ & 8 & 2 \\
\hline Simple hyperplasia & 4 & 12 \\
\hline Cystic glandular dyslasia & 0 & 2 \\
\hline $\begin{array}{l}\text { Complete hyperplasia } \\
\text { without atypia }\end{array}$ & 0 & 2 \\
\hline
\end{tabular}

All 30 cases were subjected to endometrial biopsy before starting of treatment; there was a change in the endometrial pattern after treatment.

The endometrial changes specific to progesterone receptor modulator associated endometrial changes (PAEC) which includes cystic dilatation of glands with oestrogenic (mitotic) and progesteronic secretory features, non-synchronous endometrium and abnormal 
dilated thin vessels with no evidence of atypical endometrial hyperplasia

The marked changes in the endometrium were simple endometrial hyperplasia and decrease in the normal endometrial pattern after treatment.

In the present study after starting the treatment there was reduction in menstrual blood loss observed in $90 \%$ of patients and $75 \%$ of patients' attained amenorrhea at the end of treatment. There is a Improvement in haemoglobin parameter in the study group.

The size of fibroids was also decreased (Table -6) and resistive index after treatment was raised due to loss of blood supply.

PBAC reduced significantly from 168 to 9.16 after starting the treatment and effect was noticed in the 1st cycle itself.

Table 5: Haemoglobin changes before-after treatment paired ' $t$ '-test.

\begin{tabular}{|lllll|}
\hline & Paired samples statistics & & \\
\hline & Mean & N & Std. deviation & Std. error mean \\
\hline Haemoglobin(after) & 10.9588 & 34 & 0.34034 & 0.05837 \\
\hline Haemoglobin(before) & 8.4029 & 34 & 0.31955 & 0.05480 \\
\hline
\end{tabular}

\begin{tabular}{|c|c|c|c|c|c|c|c|c|}
\hline \multicolumn{9}{|c|}{ Paired samples test } \\
\hline \multicolumn{6}{|c|}{ Paired differences } & \multirow{3}{*}{$\mathbf{t}$} & \multirow{3}{*}{ df } & \multirow{3}{*}{ Sig. (2-tailed) } \\
\hline Haemoglobin changes & \multirow[t]{2}{*}{ Mean } & \multirow[t]{2}{*}{$\begin{array}{l}\text { Std. } \\
\text { deviation }\end{array}$} & \multirow[t]{2}{*}{$\begin{array}{l}\text { Std. error } \\
\text { mean }\end{array}$} & \multicolumn{2}{|c|}{$\begin{array}{l}95 \% \text { Confidence } \\
\text { interval of the } \\
\text { difference }\end{array}$} & & & \\
\hline & & & & Lower & Upper & & & \\
\hline $\begin{array}{l}\text { Haemoglobin (after) } \\
\text { Haemoglobin (before) }\end{array}$ & 2.55588 & 0.31545 & 0.05410 & 2.44582 & 2.66595 & 47.244 & 33 & $0.000<0.001 * *$ \\
\hline
\end{tabular}

$\mathrm{P}=0.000<0.001$ highly significant.

Table 6: Ultrasound changes before-after treatment.

\begin{tabular}{|lllll|}
\hline & Paired samples statistics & & \\
\hline & Mean & N & Std. deviation & Std. error mean \\
\hline Ultrasound(before) & 59.6147 & 30 & 45.47051 & 8.30174 \\
\hline Ultrasound(after) & 26.8667 & 30 & 26.53005 & 4.84370 \\
\hline
\end{tabular}

\begin{tabular}{|c|c|c|c|c|c|c|c|c|}
\hline \multicolumn{9}{|c|}{ Paired samples test } \\
\hline \multicolumn{6}{|c|}{ Paired differences } & \multirow{3}{*}{$\mathbf{t}$} & \multirow{3}{*}{ df } & \multirow{3}{*}{ Sig. (2-tailed) } \\
\hline Ultrasound examination & \multirow[t]{2}{*}{ Mean } & \multirow{2}{*}{$\begin{array}{l}\text { Std. } \\
\text { deviation }\end{array}$} & \multirow{2}{*}{$\begin{array}{l}\text { Std. error } \\
\text { mean }\end{array}$} & \multicolumn{2}{|c|}{$\begin{array}{l}95 \% \text { Confidence interval } \\
\text { of the difference }\end{array}$} & & & \\
\hline & & & & Lower & Upper & & & \\
\hline $\begin{array}{l}\text { Ultrasound (before) } \\
\text { Ultrasound (after) }\end{array}$ & 32.748 & 34.75311 & 6.34502 & 19.77097 & 45.72503 & 5.16 & 29 & $0.000<0.001 * *$ \\
\hline
\end{tabular}

$\mathrm{P}=0.000<0.001$ highly significant.

\section{DISCUSSION}

Mifepristone as a treatment for myoma was first reported by Murphy et al. ${ }^{1}$ Further studies evaluated in doses varying from $2.5 \mathrm{mgs}$ to $50 \mathrm{mgs}$ given for 3 to 6 month and extended even up to 12 months.
The doses of mifepristone as high as $50 \mathrm{mgs}$ and as low as $5 \mathrm{mgs}$ were found effective in reducing myoma related symptoms.

The current study supports that growth of myoma is progesterone dependent also. Therefore antiprogesterone 
drug like mifepristone which is a progesterone selective receptor modulator can be effective treatment.

The treatment with mifepristone improves the haemoglobin percentage from 8.4 to 10.95 which is statistically significant (Table 5).

Clinical trial using 2.5 to $50 \mathrm{mgs}$ doses of drug were conducted for varying periods between 3 months to 12 months.

Eisinger $\mathrm{SH}$ et al reported fall of $48 \%$ in uterine volume while amenorrhoea in $61 \%$ after 6 months of treatment. ${ }^{2}$

Kettle et al reported amenorrhoea 40 to $70 \%$ over 1 year treatment of 5 to $10 \mathrm{mgs}^{3}$

In our study the dose of mifepristone was $50 \mathrm{mgs} /$ weeks for 6 month the mean blood lose declined to $95 \%$ and $75 \%$ became amenorrhic, the mean blood lose PBAC score reduced to 9.16 from 168 in the 6 month study.

Kulshrestna et al found mean PBAC score reduced from 253 to 19.8 in $25 \mathrm{mgs}$ daily group is 289 to 104 in $10 \mathrm{mg}$ groups. $^{4}$

Mechanism of reduced bleeding in myoma and myoma size is likely to be due to structural functional and microvascular effect of drug on the endometrium and uterine musculature in dose and duration. ${ }^{5}$

In our study 50mgs of drugs reduced uterine volume and size very remarkable and $(\mathrm{P}=0.000<0.001$ highly significant).

Morphy et al reported comparative study of $5 \mathrm{mgs} 25 \mathrm{mgs}$ and 50mgs suggested $25 \mathrm{mgs}$ to be the most effective dose to cause clinically significant decrease in leiomyoma.

Kapur A et al, studied efficacy of use of long term low dose mifepristone 50mgs/weekly for 6 month and concluded there was a much reduced in the size and volume of myoma. ${ }^{6}$

The antiprogesteron effect of mifepristone results in unopposed estrogen activity on the endometrium resulting in hyperplasia ${ }^{7}$.

With higher doses, activation of the hypothalamic pituitary axis may play a role. It has been showed that with higher doses drug induces rise in plasma ACTH is followed by an increase in not only plasma cortisol but also adrenal androgens and oestradial. The peripheral aromatision of adrenal androgen may lead to increased oestradial level and contributes to the proliferation of endometrium. ${ }^{8}$

Out of 30 cases 12 cases had a simple endometrial hyperplasia $26.6 \%$.
Endometrial hyperplasia is a notable adverse effect of the drug. Long term use of high dose of antiprogesterone may promote an unopposed oestrogen leading to endometrial hyperplasia.

Eisingar et al concluded $28 \%$ of patient developed simple endometrial hyperplasia. ${ }^{9}$

Mifepristone well tolerated drug with no serious adverse side effects (Spitz IM et al). ${ }^{10}$

In some cases biochemical hypothyroidism has been reported with long term administrations. Heikinheimo $\mathrm{O}$ et al in our series no cases have been reported. ${ }^{11}$

Common side effects reported are mild hot flushes seen in $10-38 \%$, Fatigue in $8-12 \%$, and increase in liver Transaminase $4-7 \%$. In our study mild hot flushes has been seen in $8 \%$, fatigue $10 \%$ and there is no raise in the live transaminase level.

Written informed consent was taking from all recruited patients.

\section{CONCLUSION}

Low dose mifepristone treatment for leiomyoma is more efficacious and useful to the patient. Drug helped in reliving the symptoms of the patient to a greater extent. The primary medical line of treatment is limited due to recurrence after stopping the treatment. This treatment is more useful to especially for perimenopausal women whose myoma regress after attaining menopause it is also useful to a women who want to postpone the surgery in some extent and it is beneficial as pre-operative adjuvant.

They tolerated the drug very well and significant improvement in quality of life. Most important and useful effect of misopristone found to be the control of bleeding leading to improvement in $\mathrm{Hb}$ and general condition with side effects of endometrial hyperplasia.

Funding: No funding sources

Conflict of interest: None declared

Ethical approval: The study was approved by the Institutional Ethics Committee

\section{REFERENCES}

1. Murphy AA. Regression of uterine leiomyoma to the RU486 dose response effect. Festly Steruly. 1995;64:187290.

2. Eisinger SH, Bonfiglio T, Fiscella K, Meldrum S, Guzick DS. Twelve month safety and efficacy of low dose mifepristone for uterine myomas. J Minim Invasive Gynecol. 2005;12:227-33.

3. Kettle IM, Murphy AA. Clinical efficiency of the RU486 the management of uterine fibroid and endometriosis human reproduction. 1994,9:116-20. 
4. Kulshrestna V, Agrawal KL. Noted low dose mifepristone in the medical management of uterine leiomyoma. Indian Journal Med Reproduction. 2013;137:1154-64.

5. Yoshida S, Ohara N, Xu Q, Chen W, Wang J, Nakabayashi K, et al. Cell-type specific actions of progesterone receptor modulators in the regulation of uterine leiomyoma growth. Semin Reprod med. 2010;28:260-73.

6. Kapur A, Dey M. Journal of OBG India 201666(SI):S494-8.

7. Bagaria. low dose of mifepristone in the treatment of myoma. Jou Obstr Gynaec. 2009;49:77-80.

8. Newfield B. Mifepristone \{RU480\} in Cushing syndrome. J Endocrinal. 2007;157:561-9.
9. Steinaur J. Systematic review of M. PV. For the treatment of uterine leiomyoma a prospective randomised placebo controlled trial. Obstrectic Gynaec. 2004;103:1331-6.

10. Spitz IM. Mifepristone; where do we come from and where are we going? Clinical development over a quarter of a century. Contraception. 2010;82:442-52.

11. Heikinheimo O, Rata S, Grunberg S, Lahteenmaki P, Spitz IM. Alterations in the pituitary-thyroid and pituitary-adrenal axes consequences of long term mifepristone treatment. Metabolism. 1997:46:292-6.

Cite this article as: Hangarga US, Rita D. Low dose mifepristone in the treatment of uterine leiomyoma. Int J Reprod Contracept Obstet Gynecol 2017;6:44-8. 